\title{
QSAR Studies and Structure Property/Activity Relationships Applied in Pyrazine Derivatives as Antiproliferative Agents Against the BGC823
}

\author{
Fatima Soualmia, ${ }^{1,2}$ Salah Belaidi, ${ }^{2, \star}$ Noureddine Tchouar, ${ }^{1}$ Touhami Lanez ${ }^{3}$ \\ and Samia Boudergua ${ }^{1,4}$ \\ ${ }^{1}$ Laboratoire Génie des Procédés et Environnement (GPE), Faculté de chimie, Université des sciences \\ et technologies d'Oran (USTO) BP 1503 Oran 31000, Algérie \\ ${ }^{2}$ University of Biskra, Group of Computational and Medicinal Chemistry, LMCE Laboratory, BP 145 Biskra 07000, Algeria \\ ${ }^{3}$ University of El-Oued, Faculty of Sciences and Technology, VTRS Laboratory, B.P.789, 39000, El-Oued, Algeria \\ ${ }^{4}$ University of KhemisMiliana, Faculty of Sciences and Technology, 44225, Ain Defla, Algeria \\ *Corresponding author: E-mail: s.belaidi@univ-biskra.dz.
}

Received: 04-08-2021

\begin{abstract}
Electronic structures, the effect of the substitution, structure physicochemical property/activity relationships and drug-likeness applied in pyrazine derivatives, have been studied at ab initio (HF, MP2) and B3LYP/DFT (density functional theory) levels. In the paper, the calculated values, i.e., NBO (natural bond orbitals) charges, bond lengths, dipole moments, electron affinities, heats of formation and quantitative structure-activity relationships (QSAR) properties are presented. For the QSAR studies, we used multiple linear regression (MLR) and artificial neural network (ANN) statistical modeling. The results show a high correlation between experimental and predicted activity values, indicating the validation and the good quality of the derived QSAR models. In addition, statistical analysis reveals that the ANN technique with (9-4-1) architecture is more significant than the MLR model. The virtual screening based on the molecular similarity method and applicability domain of QSAR allowed the discovery of novel anti-proliferative activity candidates with improved activity.
\end{abstract}

Keywords: Pyrazine; DFT; QSAR; MLR; ANN.

\section{Introduction}

Pyrazine is a heterocyclic compound containing two nitrogen atoms in its aromatic ring with molecular formula $\mathrm{C}_{4} \mathrm{H}_{4} \mathrm{~N}_{2}{ }^{1}$ it is a symmetrical molecule with point group $\mathrm{D}_{2 \mathrm{~h}}$.

Pyrazine is less basic than pyridine, pyridazine and pyrimidine. Tetramethyl pyrazine (also known as ligustrazine) is reported to scavenge superoxide anion and decrease nitric oxide production in human polymorph nuclear leukocytes and is a component of some herbs in traditional Chinese medicine. Some pyrazine derivatives contain various pharmacological effects: anti-cancer, antidepressant and anxiolytic, tuberculosis, an anti-diabetic drug and pulmonary hypertension and cardiac valve. ${ }^{2-7}$

Quantum chemistry methods play an important role in obtaining molecular structures and predicting various properties. To obtain highly accurate geometries and physical properties for molecules that are built from electronegative elements, expensive $A b$ initio/MP2 electron correlation methods are required. ${ }^{8}$ Density functional theory methods ${ }^{9-14}$ offer an alternative use of inexpensive computational methods which could handle relatively large molecules. ${ }^{15-20}$

Quantitative structure-activity relationships $(\mathrm{QSAR})^{21-25}$ are attempts to correlate molecular structure, or properties derived from molecular structure, with a particular kind of chemical or biochemical activity. The kind of activity is a function of the interest of the user. QSAR is widely used in pharmaceutical, environmental and agricultural chemistry in the search for particular properties. The molecular properties used in the correla- 
tions relate as directly as possible to the key physical or chemical processes taking place in the target activity. ${ }^{26}$

This work is planned to illuminate the theoretical determination of the optimized molecular geometries, MESP, $\mathrm{NBO}$ charges of pyrazine compounds. In addition, we calculated important quantities such as the HOMO-LUMO energy gap. ${ }^{27}$

Lipinski's 'Rule of Five'28 as well as other parameters is useful a tools to aid in choosing oral drug candidates. Drug-likeness is described to encode the balance among the molecular properties of a compound that influences its pharmacodynamics, pharmacokinetics and ADME (absorption, distribution, metabolism and excretion) in a human body like a drug. ${ }^{29}$

These parameters allow estimating oral absorption or membrane permeability, which occurs when evaluated molecules obey Lipinski's rule-of-five. Other parameters that are included the number of rotatable bonds, molecular volume, molecular polar surface area and the in vitro plasma protein binding.

The present paper deals with a specific organizational form of molecular matter. Other forms are given for example in the References. ${ }^{30-34}$

Many different chemometric methods, such as multiple linear regression (MLR), ${ }^{35}$ partial least squares regression (PLS), ${ }^{36}$ different types of artificial neural networks (ANN), ${ }^{37-40}$ genetic algorithms $(\mathrm{GA})^{41}$ and support vector machine (SVM) can be employed to deduce correlation models between the molecular structure and properties. At present, we derive a quantitative structure-activity relationship (QSAR) model using multiple linear regression (MLR) as well as artificial neural network (ANN) methods for the series of pyrazine derivatives.

The goal of the present study is to validate a suitable methodology for the accurate prediction of molecular geometries and energetic properties of potentially active compounds, and to determine the best molecular descriptors to be used in conjunction with linear (MLR) and nonlinear (ANN) QSAR models to identify the best candidates for antiproliferative agents against the BGC823. The obtained QSAR models were finally employed to identify biological activities of potentially novel active compounds using in silico screening procedures.

\section{Materials and Methods}

All calculations were performed using HyperChem 8.0.6 software ${ }^{42}$ and Gaussian 09 program package ${ }^{43}$, Marvin Sketch 6.2.1 software ${ }^{44}$, Molinspiration online database $^{45}$ and JMP 8.0.2 software. $^{46}$

The geometries of pyrazine and their methyl, ethyl, bromo, fluoro derivatives were fully optimized with $a b$ initio/HF, MP2 and DFT/B3LYP methods, using both basis set 6-311G $++(\mathrm{d}, \mathrm{p})$ and cc-pVDZ integrated with Gaussian 09 program package. The calculation of QSAR proper- ties is performed through the module QSAR properties (HyperChem version 8.0.6), which allows several properties commonly used in QSAR studies to be calculated.

Molinspiration, web-based software was used to obtain parameters such as TPSA (topological polar surface area), nrotb (number of rotatable bonds) and drug-likeness.

Multiple Linear Regression MLR analysis and artificial neural networks ANN were carried out using the software JMP 8.0.2.

The calculated results have been reported in the present work.

\section{Results and Discussion}

\section{1. Geometric and Electronic Structure of Pyrazine}

The optimized geometrical parameters of pyrazine with $a b$ initio/HF, $a b$ initio/MP2 and DFT method using 6-311G ++ (d, p) and cc-pVDZ basis set. Results concerning bond length values for pyrazine are listed in (Table 1), bond angles are listed in (Table 2) with the experimental results ${ }^{47}$ and charge densities are listed in (Table 3) are following the numbering scheme given in (Fig. 1).

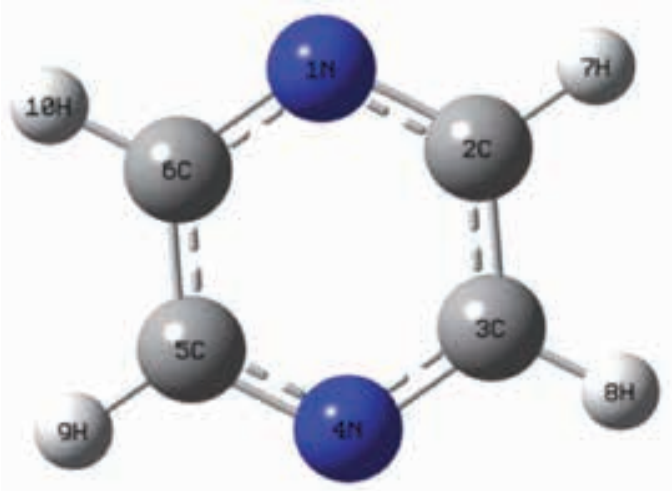

Fig. 1. 3D conformation of pyrazine (GaussView 5.0.8).

The efficiency of the DFT/B3LYP method with ccpVDZ basis set may be scrutinized by comparison with the results obtained by more elaborate calculations such as $a b$ initio/HF and MP2 methods. A very good agreement between predicted geometries (bond lengths and bond angles) and corresponding experimental data was obtained especially through the DFT/B3LYP results.

From that, we can say that the DFT method is more appropriate for further study on the pyrazine rings. Charge densities calculated by DFT/B3LYP are almost similar to $a b$ initio/HF and MP2 methods. The geometry of the pyrazine is symmetric and planar; as all the dihedral angles are either nearly $0^{\circ}$ or $180^{\circ}$, which makes this conforma- 
tion more stable. The total atomic charges of pyrazine obtained from NBO charges with DFT/B3LYP and $a b$ initio/ $\mathrm{HF}$ and MP2 methods with cc-pVDZ basis set are listed in Table 3. The atoms $\mathrm{N}$ have negative charges which lead to an electrophilic attack, the atoms $\mathrm{C}$ and $\mathrm{H}$ have a positive charges which leads to the preferential site to nucleophilic attack.

The molecular electrostatic potential surface (MESP) is a plot of electrostatic potential mapped on to the constant electron density surface. In the majority of the MESP the maximum negative region which preferred the site for an electrophilic attack is indicated in red color, while the maximum positive region which preferred the site for a nucleophilic attack is symptoms indicated in blue color. ${ }^{48}$ MESP has been found to be a very useful tool in the investigation of the correlation between the molecular structure and the physicochemical property relationship of molecules including biomolecules and drugs. ${ }^{49-53}$

The MESP surface and contour map of pyrazine (Fig. 2) show the three regions characterized by red color (negative electrostatic potential) around the tow cyclic nitrogen atoms which explain the ability of an electrophilic at- tack on these positions, also the blue color (positive electrostatic potential) around the four hydrogen atoms which explain that these regions are susceptible for a nucleophilic attack. The green color situated in the middle between the red and blue regions explains the neutral electrostatic potential surface.

Table 3. NBO charges of pyrazine molecule.

\begin{tabular}{cccc}
\hline $\begin{array}{c}\text { Pyrazine } \\
\text { Atoms }\end{array}$ & $\begin{array}{c}\text { DFT/B3LYP } \\
\text { cc-pVDZ }\end{array}$ & $\begin{array}{c}\text { Ab } \text { initio/HF } \\
\text { cc-pVDZ }\end{array}$ & $\begin{array}{c}\text { Ab } \text { initio/MP2 } \\
\text { cc-pVDZ }\end{array}$ \\
\hline $\mathrm{C}$ & 0.013 & 0.044 & 0.033 \\
$\mathrm{~N}$ & -0.456 & -0.492 & -0.487 \\
$\mathrm{H}$ & 0.215 & 0.202 & 0.210 \\
\hline
\end{tabular}

\section{2. Substitution Effect on Pyrazine Structure}

Calculated values of the two studied series indicated that in the first series methyl and ethyl groups with effects of electron donors, however, in the second series bromo and fluoro groups with effects of electron acceptors in po-

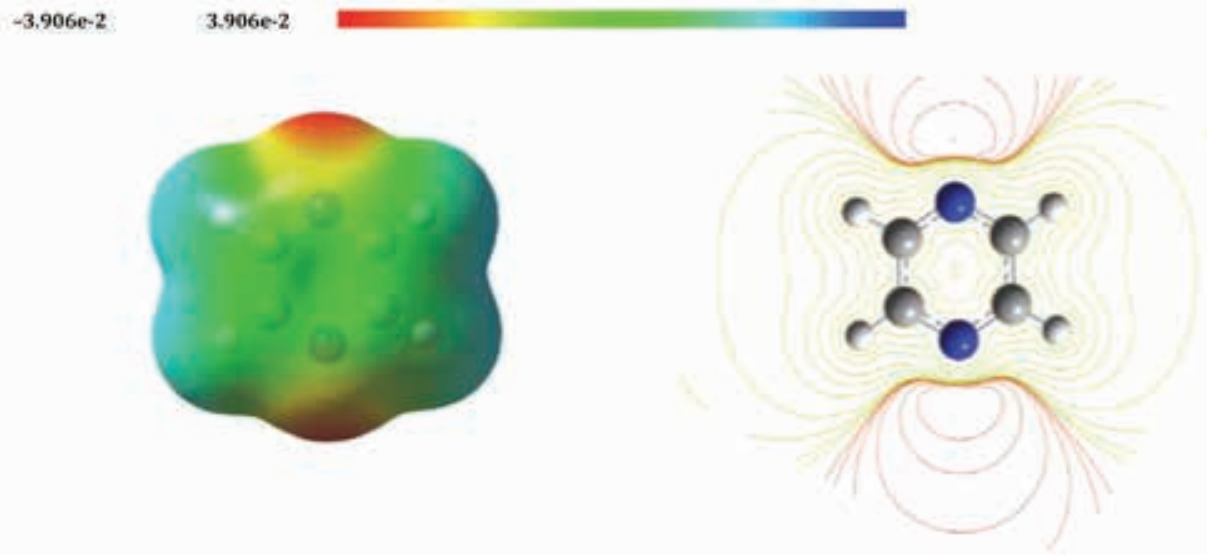

Fig. 2. 3D MESP surface map and 2D MESP contour map for pyrazine (Gauss view 5).

Table 1. Calculated bond lengths (angstrom) of pyrazine molecule.

\begin{tabular}{|c|c|c|c|c|c|c|c|}
\hline \multirow{2}{*}{ Distance } & \multirow{2}{*}{$\operatorname{EXP}^{47}$} & \multicolumn{2}{|c|}{ DFT/B3LYP } & \multicolumn{2}{|c|}{$\mathrm{Ab}$ initio/HF } & \multicolumn{2}{|c|}{ Ab initio/MP2 } \\
\hline & & $6-311 G++(d, p)$ & cc-pVDZ & $6-311 G++(d, p)$ & cc-pVDZ & $6-311 G++(d, p)$ & cc-pVDZ \\
\hline $\mathrm{C}-\mathrm{N}$ & 1.338 & 1.335 & 1.339 & 1.317 & 1.320 & 1.343 & 1.349 \\
\hline $\mathrm{C}-\mathrm{C}$ & 1.397 & 1.394 & 1.398 & 1.386 & 1.388 & 1.399 & 1.405 \\
\hline C-H & 1.083 & 1.086 & 1.095 & 1.075 & 1.082 & 1.087 & 1.096 \\
\hline
\end{tabular}

Table 2. Angles in degree of pyrazine molecule.

\begin{tabular}{|c|c|c|c|c|c|c|c|}
\hline \multirow{2}{*}{ Angle } & \multirow{2}{*}{$\operatorname{EXP}^{47}$} & \multicolumn{2}{|c|}{ DFT/B3LYP } & \multicolumn{2}{|c|}{ Ab initio/HF } & \multicolumn{2}{|c|}{$A b$ initio/MP2 } \\
\hline & & $6-311 G++(d, p)$ & cc-PVDZ & $6-311 G++(d, p)$ & cc-pVDZ & $6-311 G++(d, p)$ & cc-pVDZ \\
\hline $\mathrm{CCH}$ & 120.0 & 120.0 & 120.8 & 120.8 & 120.8 & 120.7 & 120.6 \\
\hline $\mathrm{CNC}$ & 115.7 & 116.1 & 115.6 & 116.6 & 116.3 & 115.2 & 114.6 \\
\hline
\end{tabular}


sitions C2 and C3 in the same series are given in (Table 4) and (Table 5), the heat of formation, dipole moment $(\mu)$ and HOMO (Highest Occupied Molecular Orbital) and LUMO (Lowest Unoccupied Molecular Orbital) energies of pyrazine systems are presented in (Fig. 3), NBO charges of pyrazine derivatives are reported in (Table 6) for the first series and in (Table7) for the second series. This calculation is performed with DFT/B3LYP method using the cc-pVDZ basis set.

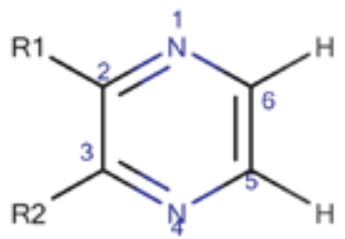

Series 1

(A1) $\mathrm{R} 1=\mathrm{H}, \mathrm{R} 2=\mathrm{H}$

(A2) $\mathrm{R} 1=\mathrm{CH} 3, \mathrm{R} 2=\mathrm{H}$

(A3) $\mathrm{R} 1=\mathrm{CH} 3, \mathrm{R} 2=\mathrm{CH} 3$

(A4) $\mathrm{R} 1=\mathrm{C} 2 \mathrm{H} 5, \mathrm{R} 2=\mathrm{H}$

(A5) $\mathrm{R} 1=\mathrm{C} 2 \mathrm{H} 5, \mathrm{R} 2=\mathrm{C} 2 \mathrm{H} 5$

\section{Series 2}

(B1) $\mathrm{R} 1=\mathrm{H}, \mathrm{R} 2=\mathrm{H}$

(B2) $\mathrm{R} 1=\mathrm{Br}, \mathrm{R} 2=\mathrm{H}$

(B3) $\mathrm{R} 1=\mathrm{Br}, \mathrm{R} 2=\mathrm{Br}$

(B4) $\mathrm{R} 1=\mathrm{F}, \mathrm{R} 2=\mathrm{H}$

(B5) $\mathrm{R} 1=\mathrm{F}, \mathrm{R} 2=\mathrm{F}$

Fig. 3. Structure of pyrazine derivatives (Marvin sketch15.8.31).

For each addition of methyl, ethyl and fluoro, the heat of formation decreases approximately 6,12 or $39(\mathrm{kcal}$ - $\mathrm{mol}^{-1}$ ) respectively but the addition of the bromo group leads to the increase of the heat of formation with $6(\mathrm{kcal}$. $\mathrm{mol}^{-1}$ ) approximately.

The Frontier orbitals, the highest occupied molecular orbital (HOMO) and lowest unoccupied molecular orbital (LUMO) are important factors in quantum chemistry ${ }^{54}$ as these determine the way the molecule interacts with other species. The frontier reactivity and kinetic stability of the molecule. A molecule with a small frontier orbital gap is more polarizable and is generally associated with a high chemical reactivity, low kinetic stability and is also termed a soft molecule. ${ }^{55}$

For the first series, it was found that electron donors of compound A4 (2-ethyl pyrazine) has the lowest energy gap HOMO-LUMO (0.1958) and compound B3 (2,3-dibromopyrazine) has the lowest energy gap $(0.1927)$ for the second series (Fig. 4).

From HSAB (Hard Soft Acid and Base) principle the lowest energetic gap allows an easy flow of electrons which makes the molecule soft and more reactive, ${ }^{56}$ which means that A4 and B3 compounds are the most reactive in the two series of pyrazine derivatives. For each addition of alkyl-substituted, the energy of the HOMO and LUMO increase respectively but the addition of the fluoro, bromo substituted leads to the decrease of the LUMO energy an exception increase of the bromo substituted and decrease of the fluoro substituted of the HOMO. The carbon C2 has the most important positive charge $(0.206)$ in the compound A4 (2-ethyl pyrazine) for the first series, also for compound B3 (2,3-dibromopyrazine) of the second series, the most important positive charges are on carbon $\mathrm{C} 2$ (0.102) and C3 (0.102) as shown in (Table 5), these positions C2 and C3 with the important positive charges lead to preferential sites of nucleophilic attack. The compound $\mathrm{B} 3$ is predicted to be the most reactive with a smaller $\mathrm{HO}$ MO-LUMO energy gap and with sites of nucleophilic attack, more stable with the maximum value in the heat of formation.

The contour plots of the $\pi$ like frontier orbital for the ground state of the compound B3 are shown in (Fig. $4)$.

From the plots, we can observe that the HOMO is a $\pi$ bonding molecular orbital developed on $\mathrm{C} 5$ and $\mathrm{C} 6$ atoms, and the LUMO is a $\pi^{\star}$ anti-bonding molecular orbit-

Table 4. Energies of pyrazine and methyl, ethyl-substituted pyrazine.

\begin{tabular}{lcccccc}
\hline & $\begin{array}{c}\Delta \mathbf{H}_{\mathbf{f}} \\
{[\mathbf{k c a l} / \mathbf{m o l}]}\end{array}$ & $\begin{array}{c}\text { HOMO } \\
{[\mathbf{a u}]}\end{array}$ & $\begin{array}{c}\text { LUMO } \\
{[\mathbf{a u}]}\end{array}$ & $\begin{array}{c}\Delta \mathrm{E} \\
{[\mathbf{a u}]}\end{array}$ & $\begin{array}{c}\boldsymbol{\mu} \\
{[\text { Debye }]}\end{array}$ \\
\hline $\mathbf{A 1}$ & Pyrazine & 44.09 & -0.252 & -0.055 & 0.197 & 0.00 \\
$\mathbf{A 2}$ & 2-methyl pyrazine & 37.05 & -0.247 & -0.051 & 0.196 & 0.59 \\
$\mathbf{A 3}$ & 2,3-di-methyl pyrazine & 31.78 & -0.243 & -0.044 & 0.199 & 0.80 \\
$\mathbf{A 4}$ & 2-ethyl pyrazine & 30.97 & -0.247 & -0.051 & 0.195 & 0.59 \\
$\mathbf{A 5}$ & 2,3-di-ethyl pyrazine & 20.48 & -0.242 & -0.045 & 0.196 & 0.69 \\
\hline
\end{tabular}

Table 5. Energies of pyrazine and fluoro, bromo-substituted pyrazine.

\begin{tabular}{lcccccc}
\hline & $\begin{array}{c}\Delta \mathbf{H}_{\mathbf{f}} \\
{[\mathbf{k c a l} / \mathbf{m o l}]}\end{array}$ & $\begin{array}{c}\text { HOMO } \\
{[\mathbf{a u}]}\end{array}$ & $\begin{array}{c}\text { LUMO } \\
{[\mathbf{a u}]}\end{array}$ & $\begin{array}{c}\Delta \mathrm{E} \\
{[\mathbf{a u}]}\end{array}$ & $\begin{array}{c}\boldsymbol{\mu} \\
{[\text { Debye] }}\end{array}$ \\
\hline B1 & Pyrazine & 44.09 & -0.253 & -0.055 & 0.197 & 0.00 \\
B2 & 2-bromopyrazine & 49.73 & -0.269 & -0.068 & 0.201 & 1.50 \\
B3 & 2,3-dibromopyrazine & 55.88 & -0.268 & -0.075 & 0.192 & 2.05 \\
B4 & 2-fluoro pyrazine & 04.15 & -0.272 & -0.065 & 0.207 & 1.33 \\
B5 & 2,3-di-fluoropyrazine & -33.52 & -0.280 & -0.069 & 0.211 & 2.24 \\
\hline
\end{tabular}


Table 6. NBO charges of pyrazine series 1.

\begin{tabular}{lccccc}
\hline & A1 & A2 & A3 & A4 & A5 \\
\hline N1 & -0.456 & -0.472 & -0.471 & -0.476 & -0.476 \\
N4 & -0.456 & -0.452 & -0.473 & -0.452 & -0.472 \\
C2 & 0.013 & 0.204 & 0.215 & 0.206 & 0.216 \\
C3 & 0.013 & 0.016 & 0.208 & 0.020 & 0.213 \\
C5 & 0.013 & 0.003 & 0.010 & 0.004 & 0.013 \\
C6 & 0.013 & 0.022 & 0.012 & 0.023 & 0.015 \\
C-methyl- 2 & - & -0.665 & -0.669 & - & - \\
C-methyl -3 & - & - & -0.673 & - & - \\
C'-ethyl- 2 & - & - & - & -0.458 & -0.459 \\
C $^{2}$-ethyl -2 & - & - & - & -0.628 & -0.627 \\
C $^{1}$-ethyl -3 & - & - & - & - & -0.461 \\
C $^{2}$-ethyl-3 & - & - & - & - & -0.627 \\
\hline
\end{tabular}

Table 7. NBO charges of pyrazine series 2 .

\begin{tabular}{lccccc}
\hline & B1 & B2 & B3 & B4 & B5 \\
\hline N1 & -0.456 & -0.458 & -0.446 & -0.497 & -0.485 \\
N4 & -0.456 & -0.441 & -0.446 & -0.441 & -0.485 \\
C2 & 0.013 & 0.112 & 0.102 & 0.634 & 0.586 \\
C3 & 0.013 & 0.018 & 0.102 & -0.040 & 0.586 \\
C5 & 0.013 & 0.006 & 0.018 & -0.008 & 0.002 \\
C6 & 0.013 & 0.024 & 0.018 & 0.024 & 0.002 \\
Brome-2 & - & 0.064 & 0.100 & - & - \\
Brome-3 & - & - & 0.100 & - & - \\
Fluor-2 & - & - & - & -0.338 & -0.327 \\
Fluor-3 & - & - & - & - & -0.327 \\
\hline
\end{tabular}

al developed on the N1 and C2 atoms. These further demonstrates the existence of the delocalization of the conjugated $\pi$-electron system in 2, 3-dibromopyrazine molecule. Dipole moment equal to zero which confirms the symmetry group $\mathrm{D}_{2 \mathrm{~h}}$ of pyrazine. The compound $\mathrm{B} 5$ (2,3-di-fluoropyrazine) also shows a high dipole moment value (2.2435 Debye).
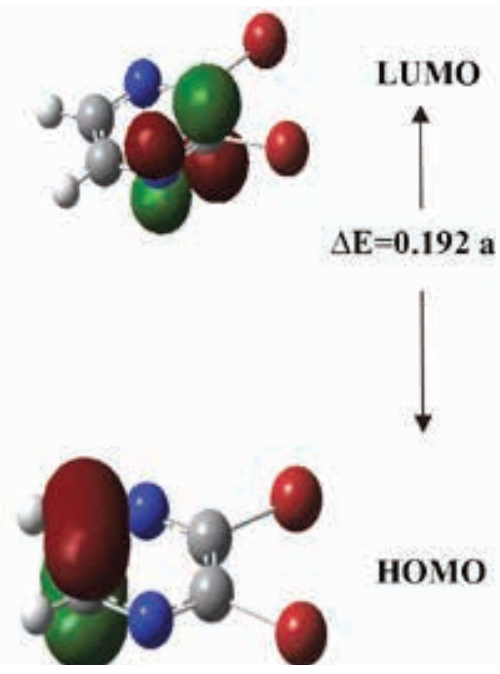

Fig. 4. $\pi$ like frontier orbitals of the compound B3.

\section{3. Structure Activity/Property Relationship for Pyrazine Derivatives}

For the series of pyrazine derivatives (Fig. 8) we have studied seven physicochemical properties with respect to their anti-proliferative activity against the BGC823 (human gastric cell). ${ }^{57}$ The properties involved are: Surface area grid (SAG), molar volume (V), hydration energy (HE), partition coefficient octanol/water $(\log \mathrm{P})$, molar refractivity (MR), polarizability (Pol) and molecular weight (MW).

The results obtained using HyperChem 8.0.8 software are shown in Table 8. For example, Fig. 5 shows the favored conformation in 3D of compound 1.

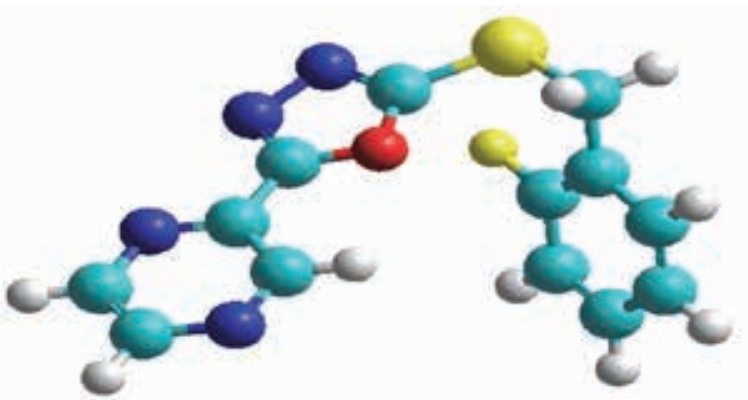

Fig. 5. 3D Conformation of compound 1 (HyperChem 8.03). 
Table 8. QSAR properties of pyrazine derivatives.

\begin{tabular}{|c|c|c|c|c|c|c|c|}
\hline Compounds & $\begin{array}{c}\text { MW } \\
\text { [amu] }\end{array}$ & $\begin{array}{l}\text { SAG } \\
{\left[\mathbf{A}^{\circ 2}\right]}\end{array}$ & $\begin{array}{c}\mathbf{V} \\
{\left[\mathbf{A}^{\circ 3}\right]}\end{array}$ & $\begin{array}{c}\text { Pol } \\
{\left[\mathbf{A}^{\circ 3}\right]}\end{array}$ & $\begin{array}{c}\text { MR } \\
{\left[\mathbf{A}^{\circ 3}\right]}\end{array}$ & $\log P$ & $\begin{array}{c}\mathrm{HE} \\
{[\mathrm{kcal} / \mathrm{mol}]}\end{array}$ \\
\hline 1 & 288.30 & 466.47 & 770.17 & 28.82 & 79.14 & 1.94 & -12.54 \\
\hline 2 & 304.75 & 474.61 & 791.62 & 30.84 & 83.73 & 2.32 & -12.63 \\
\hline 3 & 349.20 & 485.20 & 810.26 & 31.54 & 86.54 & 2.60 & -12.58 \\
\hline 4 & 304.75 & 498.29 & 809.75 & 30.84 & 83.73 & 2.32 & -13.29 \\
\hline 5 & 349.20 & 505.96 & 828.55 & 31.54 & 86.54 & 2.6 & -13.24 \\
\hline 6 & 320.81 & 512.80 & 828.87 & 33.20 & 90.17 & 2.67 & -11.30 \\
\hline 7 & 304.36 & 486.18 & 800.84 & 31.18 & 85.58 & 2.29 & -11.39 \\
\hline 8 & 320.81 & 498.70 & 822.05 & 33.20 & 90.17 & 2.67 & -12.25 \\
\hline 9 & 424.32 & 628.79 & 1054.66 & 41.91 & 118.37 & 3.13 & -11.55 \\
\hline 10 & 363.41 & 543.20 & 948.38 & 39.20 & 110.97 & 2.48 & -11.54 \\
\hline 11 & 379.87 & 550.54 & 984.28 & 41.21 & 115.56 & 2.86 & -10.69 \\
\hline 12 & 424.32 & 554.53 & 997.06 & 41.91 & 118.37 & 3.13 & -10.63 \\
\hline 13 & 379.87 & 562.49 & 980.74 & 41.21 & 115.56 & 2.86 & -11.45 \\
\hline 14 & 363.41 & 543.20 & 948.38 & 39.20 & 110.97 & 2.48 & -11.54 \\
\hline 15 & 270.31 & 475.71 & 769.23 & 28.91 & 79.01 & 2.55 & -13.67 \\
\hline 16 & 286.37 & 490.32 & 789.01 & 31.27 & 85.45 & 2.89 & -12.89 \\
\hline 17 & 349.20 & 517.21 & 832.69 & 31.54 & 86.54 & 2.60 & -14.62 \\
\hline 18 & 306.29 & 476.68 & 771.74 & 28.73 & 79.26 & 1.34 & -13.64 \\
\hline
\end{tabular}

Molar refractivity and polarizability relatively increase with the size and the molecular weight of the studied pyrazine derivatives (Table 8 and fig.6). This result is in agreement with the formula of Lorentz-Lorenz, which gives a relationship between polarizability, molar refractivity and molecular size.

From the obtained results presented in Table 8 and figure 6, we observed that polarizability data and molecular refractivity are generally proportional to the size and the molecular weight of pyrazine derivatives. This explains the congruity of our results with Lorentz-Lorenz expression. For instance, compound 9 and compound 12 show the same maximum values of polarizability $\left(41.91\left(\AA^{3}\right)\right)$ and refractivity $\left(118.37\left(\AA^{3}\right)\right)$. These compounds have also high values of molecular weight (424.32 uma), and a slight difference in surfaces and volumes.

Hydration energy in absolute value, the most important is that of the compound $17\left(14.62 \mathrm{kcal} \cdot \mathrm{mol}^{-1}\right)$ and the smallest value is that of the compound $12(10.63 \mathrm{kcal}$. $\left.\mathrm{mol}^{-1}\right)$. Indeed, in biological environments, the polar molecules are surrounded by water molecules. They have established hydrogen bonds between them.

Hydrophobic groups in pyrazine derivatives induce a decrease of hydration energy.

However, the lipophilie increases proportionally with the hydrophobic features of the substituent. As seen in Table 8, compound 17 is expected to have the highest hydrophilicity, whereas compound number 12 should be

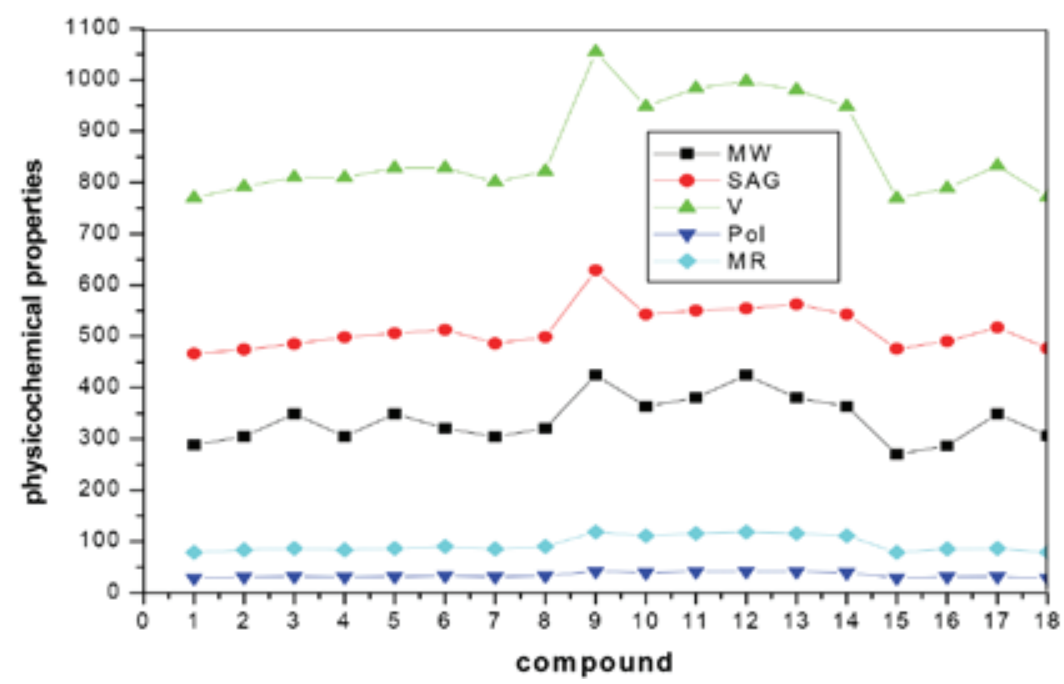

Fig. 6. Graphical representation of physicochemical properties. 
most lipophilic. This implies that these compounds should have poor permeability across the cell membrane.

We noticed that compound 17 possess seven hydrogen bond acceptors (HBA) and no hydrogen bond donors (HBD), the presence of hydrophilic groups in this compound result in an increase of the hydration energy. This property explains the ability of these compounds, not only to fix the receptor but also to activate it. Hydration energy measures the degree of agonist character of a potential drug molecule.

Almost $(\log \mathrm{P})$ of studied molecules have optimal values. For good oral bioavailability, the $\log \mathrm{P}$ must be greater than zero and less than $3(0<\log \mathrm{P}<3)$. For very high values of $\log \mathrm{P}$, the drug has low solubility and for very low values of $\log \mathrm{P}$; the drug has difficulty penetrating the lipid membranes. Thus, compound 17 has the most important hydration energy and the optimal value of $\log \mathrm{P}$, the small value of molecular weight leading to better distribution and solubility in fabrics, good oral bioavailability and permeability in cellular membranes respectively (Fig. 7).

\section{4. Drug-Likeness Screening Applied in Pyrazine Derivatives}

We have applied rules of thumb and calculated metrics of eighteen derivatives of pyrazine (Fig. 8) taken from literature with their anti-proliferative activity against the BGC823. ${ }^{57}$

The properties involved are: octanol/water partition coefficient $(\log \mathrm{P})$, molecular weight $(\mathrm{MW})$, hydrogen bond donors (HBD), hydrogen bond acceptors (HBA), number of rotatable bonds (NRB) and polar surface area (TPSA). All the results have been calculated using HyperChem 8.0.8 and Marvin Sketch 6.2.1 software, which are listed respectively in Table 9, we have studied Lipinski and Veber rules to identify "drug-like" compounds: ${ }^{58,59}$

(1) There are less than $5 \mathrm{H}$-bond donors (expressed as the sum of $\mathrm{OHs}$ and $\mathrm{NHs}$ ).

(2) The molecular weight is under $500 \mathrm{DA}$.

(3) The $\log \mathrm{P}$ is under 5.

(4) There are less than $10 \mathrm{H}$-bond acceptors (expressed as the sum of Ns and Os).

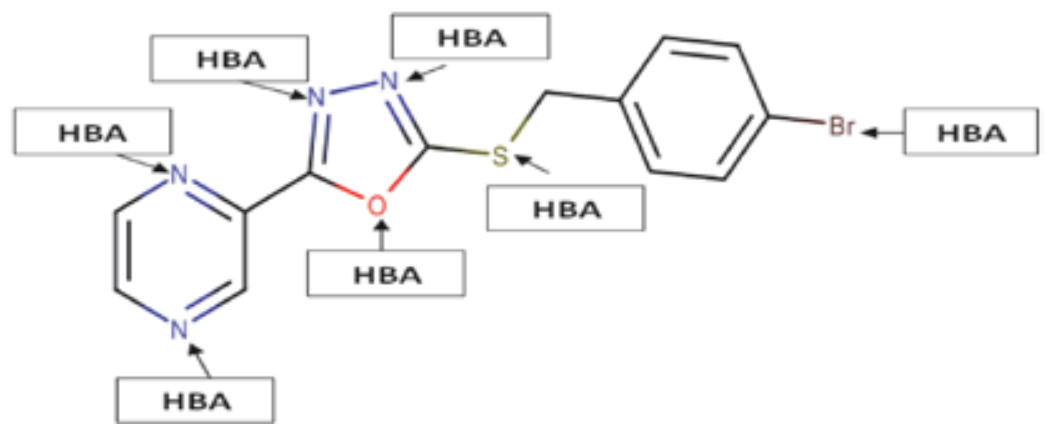

Fig. 7. Acceptor sites of proton for compound 17.

Table 9. Pharmacological activities and properties involved in MPO methods for drug-likeness of pyrazine derivatives.

\begin{tabular}{|c|c|c|c|c|c|c|c|}
\hline \multirow[t]{2}{*}{$\mathbf{N}^{\circ}$} & \multirow[t]{2}{*}{$\mathrm{pIC} 50_{\mathrm{BGC} 823}{ }^{57}$} & \multicolumn{4}{|c|}{ Lipinski's rule } & \multicolumn{2}{|c|}{ Veber rules } \\
\hline & & $\begin{array}{c}\log P \\
<5\end{array}$ & $\begin{array}{c}\text { MW } \\
\text { [amu] }\end{array}$ & $\begin{array}{c}\text { HBA } \\
<10\end{array}$ & $\begin{array}{c}\text { HBD } \\
<5\end{array}$ & $\begin{array}{c}\text { NRB } \\
<10\end{array}$ & $\begin{array}{c}\text { TPSA }\left[\mathrm{A}^{\circ 2}\right] \\
\quad<\mathbf{1 4 0}\end{array}$ \\
\hline 1 & 4.74 & 1.94 & 288.30 & 5 & 0 & 4 & 64.71 \\
\hline 2 & 4.56 & 2.32 & 304.75 & 5 & 0 & 4 & 64.71 \\
\hline 3 & 4.76 & 2.60 & 349.20 & 5 & 0 & 4 & 64.71 \\
\hline 4 & 4.8 & 2.32 & 304.75 & 5 & 0 & 4 & 64.71 \\
\hline 5 & 4.94 & 2.6 & 349.20 & 5 & 0 & 4 & 64.71 \\
\hline 6 & 4.87 & 2.67 & 320.81 & 4 & 0 & 4 & 51.57 \\
\hline 7 & 4.73 & 2.29 & 304.36 & 4 & 0 & 4 & 51.57 \\
\hline 8 & 4.69 & 2.67 & 320.81 & 4 & 0 & 4 & 51.57 \\
\hline 9 & 4.70 & 3.13 & 424.32 & 5 & 0 & 5 & 56.50 \\
\hline 10 & 4.53 & 2.48 & 363.41 & 4 & 0 & 4 & 51.57 \\
\hline 11 & 4.46 & 2.86 & 379.87 & 5 & 0 & 5 & 56.50 \\
\hline 12 & 4.44 & 3.13 & 424.32 & 5 & 0 & 5 & 56.50 \\
\hline 13 & 4.69 & 2.86 & 379.87 & 5 & 0 & 5 & 56.50 \\
\hline 14 & 4.57 & 2.48 & 363.41 & 5 & 0 & 5 & 56.50 \\
\hline 15 & 4.60 & 2.55 & 270.31 & 5 & 0 & 4 & 64.71 \\
\hline 16 & 4.67 & 2.89 & 286.37 & 4 & 0 & 4 & 51.57 \\
\hline 17 & 4.59 & 2.60 & 349.20 & 5 & 0 & 4 & 64.71 \\
\hline 18 & 4.48 & 1.34 & 306.29 & 5 & 0 & 4 & 64.71 \\
\hline
\end{tabular}


(5) Rotatable bonds are under 10.

(6) TPSA is under $140 \AA^{2}$

All the compounds of the series have the MW under 500 DA, thus they can easily pass through the cell membrane and the better the absorption will be.

There are less than $10 \mathrm{H}$-bond acceptors and 0 $\mathrm{H}$-bond donors, the fat solubility will be high and therefore the drug will be able to penetrate the cell membrane to reach the inside of the cell. If two of these rules are unsatisfied, the compound will have a problem in absorption and permeability. ${ }^{60}$

TPSA of pyrazine derivatives was found in the range of 52.325-65.217 $\mathrm{A}^{\circ 2}$ and is well below $140 \AA^{2}$, indicating that these compounds should have good cellular plasmatic membrane permeability. All the screened compounds were flexible, especially; compounds 9 and 11-14 which have 5 rotatable bonds (table 9 ).

\section{5. Quantitative Structure-Activity Relationships Studies (QSAR) of Pyrazine Derivatives}

When chemical or physical properties and molecular structures are derived from numbers, it is often possi- ble to propose mathematical relations connecting them, which allow making quantitative predictions. The obtained mathematical expressions can then be used as a predictive means of the biological response for similar structures. They are widely used in the pharmaceutical industry to identify promising compounds, especially at the early stages of drug discovery. ${ }^{61}$

Relationships between the physicochemical properties of chemical substances and their biological activities can be derived using QSAR (Quantitative Structure-Activity Relationships) concept. These models can also be used to predict the activities of new chemical entities and for their design. ${ }^{62}$ therefore, the biological activity is quantitatively expressed as the concentration of substance necessary to obtain a certain biological response. For that purpose, multiple linear regression, MLR, and artificial neural networks (ANNs) are used. The accuracy of such models is mainly evaluated by the correlation coefficient $\mathrm{R}^{2} .{ }^{63}$ The MLR and ANN models were generated using JMP 8.0.2 software.

The equilibrium geometries and the highest occupied molecular orbital energy $\left(\mathrm{E}_{\mathrm{HOMO}}\right)$ and lowest unoccupied molecular orbital energy ( $\left.\mathrm{E}_{\mathrm{LUMO}}\right)$ and dipole moment $(\mu)$ of pyrazine derivatives were determined at the B3LYP/cc-pVDZ level of theory. We list in table 10 of the

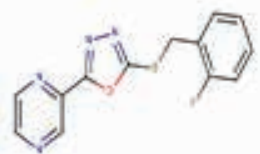

1

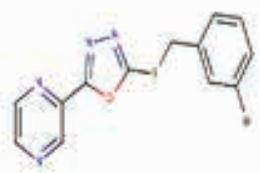

5

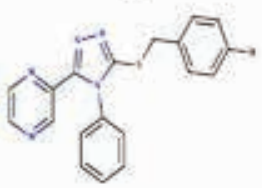

9

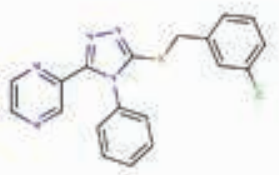

13

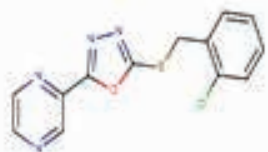

2

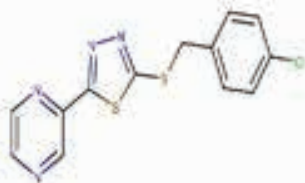

6

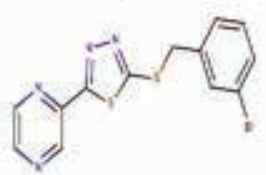

10

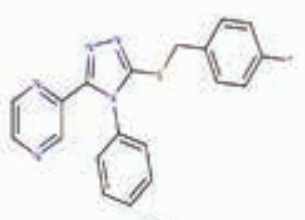

14

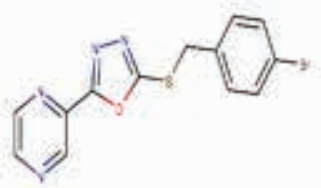

17

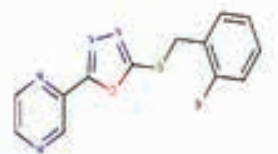

3

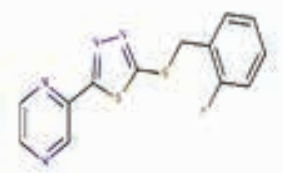

7

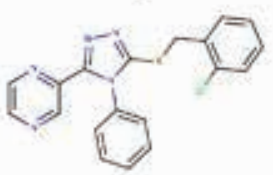

11

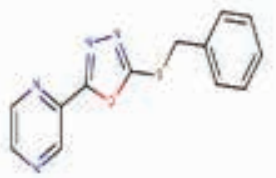

15

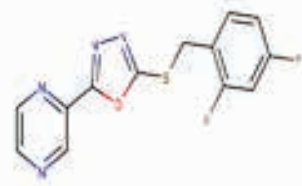

18

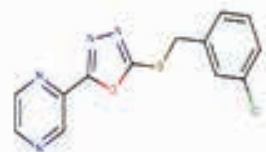

4<smiles>Fc1ccccc1CSc1ncc(-c2ccccc2)s1</smiles>

8

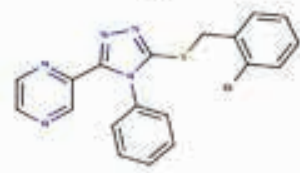

12

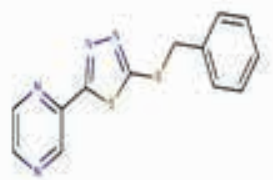

16

Fig. 8. Structural comparison of pyrazine derivatives. 
Table 10.Values of molecular descriptors.

\begin{tabular}{cccccccccccc}
\hline $\mathbf{N}^{\circ}$ & $\mathbf{p I C 5 0}_{\mathbf{B G C 8 2 3}}{ }^{\mathbf{5 7}}$ & $\begin{array}{c}\mathbf{V} \\
{\left[\mathbf{A}^{\mathbf{0 3}}\right]}\end{array}$ & $\begin{array}{c}\mathbf{H E} \\
{[\mathbf{k c a l} / \mathbf{m o l}]}\end{array}$ & $\mathbf{L o g} \mathbf{P}$ & $\begin{array}{c}\mathbf{M R} \\
{\left[\mathbf{A}^{\mathbf{0 3}}\right]}\end{array}$ & $\begin{array}{c}\mathbf{S A G} \\
{\left[\mathbf{A}^{\mathbf{0 2}}\right]}\end{array}$ & $\begin{array}{c}\mathbf{M W} \\
{[\mathbf{a m u}]}\end{array}$ & $\begin{array}{c}\text { Pol } \\
{\left[\mathbf{A}^{\text {o3 }}\right]}\end{array}$ & $\begin{array}{c}\mathbf{E}_{\mathbf{H O M O}} \\
{[\mathbf{a u}]}\end{array}$ & $\begin{array}{c}\mathbf{E}_{\mathbf{L U M O}} \\
{[\mathbf{a u}]}\end{array}$ & $\begin{array}{c}\boldsymbol{\mu} \\
{[\mathbf{D e b y e}]}\end{array}$ \\
\hline 1 & 4.740 & 770.170 & -12.540 & 1.940 & 79.140 & 466.470 & 288.300 & 28.820 & -0.239 & -0.079 & 0.886 \\
2 & 4.560 & 791.620 & -12.630 & 2.320 & 83.730 & 474.610 & 304.750 & 30.840 & -0.249 & -0.081 & 5.144 \\
3 & 4.760 & 810.260 & -12.580 & 2.600 & 86.540 & 485.200 & 349.200 & 31.540 & -0.240 & -0.080 & 0.887 \\
4 & 4.800 & 809.750 & -13.290 & 2.320 & 83.730 & 498.290 & 304.750 & 30.840 & -0.243 & -0.081 & 1.269 \\
5 & 4.940 & 828.550 & -13.240 & 2.600 & 86.540 & 505.960 & 349.200 & 31.540 & -0.247 & -0.082 & 1.498 \\
$6^{*}$ & 4.870 & 828.870 & -11.300 & 2.670 & 90.170 & 512.800 & 320.810 & 33.200 & -0.236 & -0.086 & 2.564 \\
7 & 4.730 & 800.840 & -11.390 & 2.290 & 85.580 & 486.180 & 304.360 & 31.180 & -0.234 & -0.084 & 5.024 \\
8 & 4.690 & 822.050 & -12.250 & 2.670 & 90.170 & 498.700 & 320.810 & 33.200 & -0.235 & -0.086 & 5.023 \\
$9^{*}$ & 4.700 & 1054.660 & -11.550 & 3.130 & 118.370 & 628.790 & 424.320 & 41.910 & -0.223 & -0.065 & 4.262 \\
10 & 4.530 & 948.380 & -11.540 & 2.480 & 110.970 & 543.200 & 363.410 & 39.200 & -0.223 & -0.064 & 4.275 \\
$11^{*}$ & 4.460 & 984.280 & -10.690 & 2.860 & 115.560 & 550.540 & 379.870 & 41.210 & -0.220 & -0.063 & 4.963 \\
12 & 4.440 & 997.060 & -10.630 & 3.130 & 118.370 & 554.530 & 424.320 & 41.910 & -0.220 & -0.063 & 4.949 \\
13 & 4.690 & 980.740 & -11.450 & 2.860 & 115.560 & 562.490 & 379.870 & 41.210 & -0.224 & -0.067 & 4.190 \\
14 & 4.570 & 948.380 & -11.540 & 2.480 & 110.970 & 543.200 & 363.410 & 39.200 & -0.223 & -0.064 & 4.275 \\
15 & 4.600 & 769.230 & -13.670 & 2.550 & 79.010 & 475.710 & 270.310 & 28.910 & -0.240 & -0.081 & 4.278 \\
16 & 4.670 & 789.010 & -12.890 & 2.890 & 85.450 & 490.320 & 286.370 & 31.270 & -0.233 & -0.083 & 1.449 \\
17 & 4.590 & 832.690 & -14.620 & 2.600 & 86.540 & 517.210 & 349.200 & 31.540 & -0.241 & -0.081 & 4.127 \\
18 & 4.480 & 771.740 & 13.640 & 1.340 & 79.260 & 476.680 & 306.290 & 28.730 & -0.243 & -0.084 & 4.472 \\
\hline
\end{tabular}

* denotes the selected compounds for external validation (test set).

supplementary material the Cartesian coordinates of the optimized pyrazine derivatives equilibrium structures. Then, the QSAR properties module from Hyper Chem 8.08 was used to calculate: molar weight (MW), surface area (SAG), volume (V), molar refractivity (MR), polarizability (Pol), octanol-water partition coefficient (log P) and hydration energy (HE).

\section{5. 1. Multiple Linear Regression (MLR)}

Despite being the oldest, $\mathrm{MLR}^{64,65}$ still remains one of the most popular approaches to build QSAR models. This is due to its simple practicaluse, ease of interpretation and transparency. Indeed, the key algorithm is available and accurate predictions can be provided. ${ }^{66}$ The values of the calculated descriptors are those listed in Table 10. Data were randomly divided into two groups: a training set (internal validation) and a testing set (external validation) at a ratio of 80:20. A correlation matrix between parameters was performed on all nine descriptors. Nevertheless, the analysis revealed six independent descriptors for the development of the model. The significant correlation analysis between biological activity and descriptors is represented by the following equation:

$$
\begin{aligned}
& \text { pIC50 }_{\text {BGC823 }}=-6.878+0.0115 \\
& \text { V-0.0134HE }+0.1763 \text { MR-0.0087 } \\
& \text { SAG-0.004355MAG-0.5185Pol-15.46 } \\
& \text { E }_{\text {HOMO }}-66.309 E_{\text {LUMO }}-0.067 \mu
\end{aligned}
$$

Where, pIC50 is the response or dependent variable (V, HE, MR, SAG, MAG, Pol, EHOMO, E $\mathrm{LUMO}_{\mathrm{O}}$ and $\mu$ ) are descriptors (features or independent variables). Within the regression, the coefficients in front of these descriptors are optimized.

The $\mathrm{F}$ value ( $\mathrm{F}=11.84)$ was found to be statistically significant at $95 \%$ level, since all the calculated $\mathrm{F}$ value is higher as compared to tabulated values.

For validation of the model, we plot in Fig. 9 the experimental activities against the predicted values as determined by equation (1). We can observe that the predicted pIC50 values are in an acceptable agreement and regular distribution with experimental ones with correlation coefficient $\left(\mathrm{R}^{2}\right)$ for the training set $\left(R_{\text {inter }}^{2}=0.955\right)$ and test set $\left(R_{\text {ext }}^{2}=0.930\right)$ indicate the significant correlation between different independent variables with anti-proliferative activity against the BGC823.

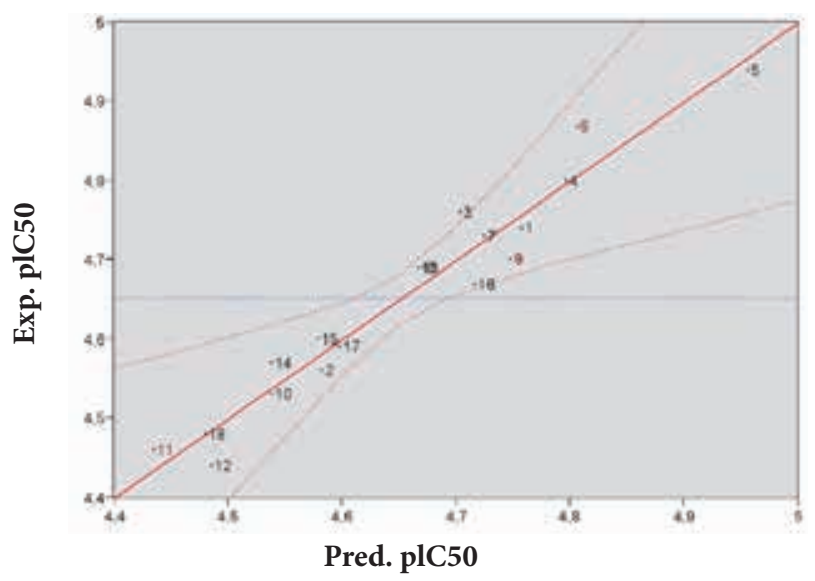

Fig. 9. Correlation of experimental and predicted pIC50 values as derived using MLR 


\section{5. 2. Artificial Neural Networks}

$\mathrm{ANN}^{67-70}$ is a popular nonlinear model, used to predict the biological activity (i.e. IC50) of the datasets of therapeutic molecules. It presents several benefits like better prediction, adaptation and generalization capacity beyond the studied sample, and better stability of the coefficients. It is employed in complex drug design, drug engineering and medicinal chemistry domains. ${ }^{71}$ In this work, the neural network is a system of fully interconnected neurons arranged in three layers. The input layer is made of nine neurons, where each of them receives one of the nine descriptors selected from the correlation matrix of the model. The intermediate (hidden) layer is composed of four neurons that form the deep internal pattern that discovers the most significant correlations between predicted and experimental data. One neuron constitutes the output layer, which returns the value of pIC50 (Fig. 10). ${ }^{72}$

As it can be seen in Fig. 10, a good agreement between experimental data and predicted pIC50 issued from the ANN model is observed. Indeed, the statistical parameters for this model, reveal a correlation coefficient close to 1 (= 0.995), indicating that the ANN one is more reliable. Furthermore, the robustness of the model was further confirmed by the significant value of the test data set $(=0.920)$.

\section{5. 3. Virtual Screening Application}

The aim of this study is to identify new structures of pyrazines $^{73}$ with improved anti-proliferative activity against BGC823 that has to be within the applicability do-

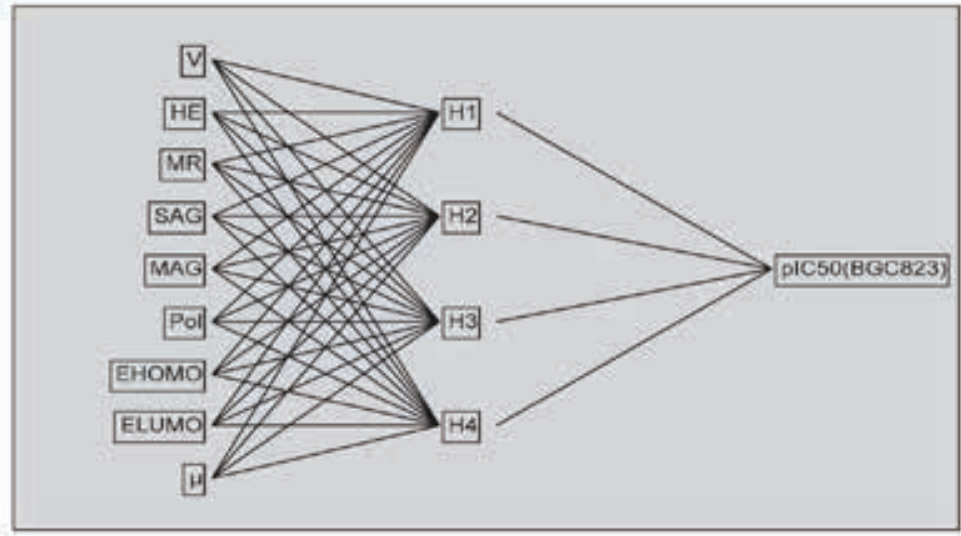

Fig. 10. Structure of ANN.

Table 11. Experimental and predicted pIC50 values using MLR and ANN methods.

\begin{tabular}{cccc}
\hline $\mathbf{N}^{\circ}$ & Exp. pIC50(BGC823) & $\begin{array}{c}\text { Pred. pIC50(BGC823) } \\
\text { MLR }\end{array}$ & $\begin{array}{c}\text { Pred.pIC50(BGC823) } \\
\text { ANN }\end{array}$ \\
\hline 1 & & 4.757 & 4.736 \\
2 & 4.740 & 4.582 & 4.562 \\
3 & 4.560 & 4.704 & 4.764 \\
4 & 4.760 & 4.796 & 4.804 \\
5 & 4.800 & 4.956 & 4.931 \\
$6^{*}$ & 4.940 & 4.806 & 4.869 \\
7 & 4.870 & 4.724 & 4.717 \\
8 & 4.730 & 4.671 & 4.696 \\
$9^{*}$ & 4.690 & 4.748 & 4.642 \\
10 & 4.700 & 4.537 & 4.550 \\
$11^{\star}$ & 4.530 & 4.434 & 4.521 \\
12 & 4.460 & 4.485 & 4.443 \\
13 & 4.440 & 4.666 & 4.686 \\
14 & 4.690 & 4.537 & 4.550 \\
15 & 4.570 & 4.579 & 4.603 \\
16 & 4.600 & 4.716 & 4.672 \\
17 & 4.670 & 4.598 & 4.595 \\
18 & 4.590 & 4.480 & 4.481 \\
\hline
\end{tabular}

* denotes the compounds selected for external validation (test set). 


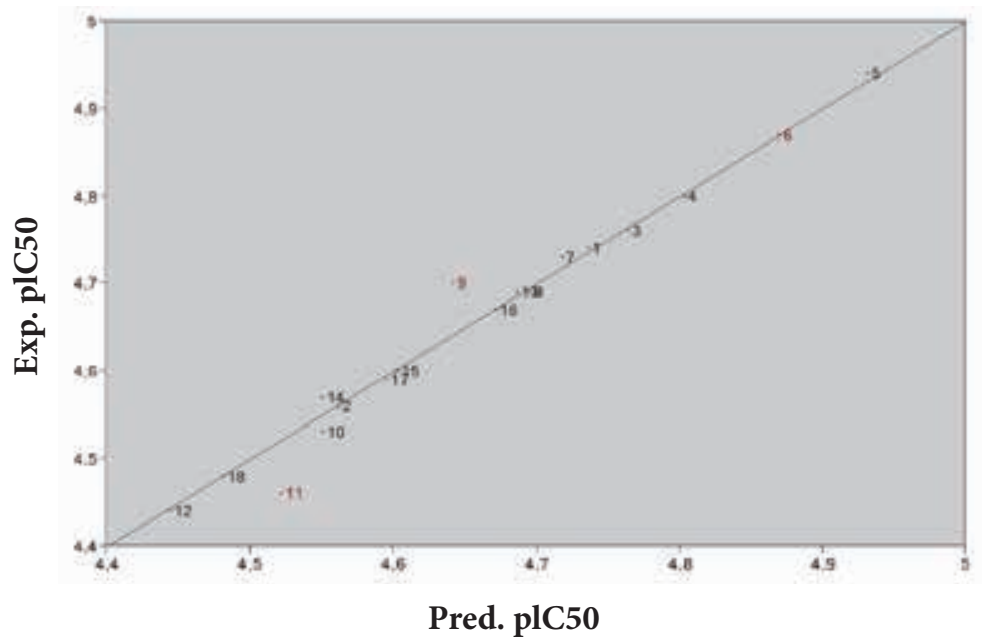

Fig. 11. Correlation of experimental and predicted pIC50 values obtained using ANN.

Table 12. Proposed structural compounds and predicted activities.

No. Compound struct

2<smiles>CCc1nc(C)c(C)nc1C</smiles>

3<smiles>CCCc1nc(C)c(C)nc1CC</smiles>

4<smiles>COc1ccc(-c2nccnc2-c2ccc(O)cc2)cc1</smiles>

5<smiles>Cc1nc(-c2ccccc2)cnc1C#N</smiles>

6<smiles>c1ccc(-c2nccnc2-c2ccccc2)cc1</smiles>

5.789

4.495

2.941

6.907

3.878
No.

Compound structure

pIC50

7<smiles>COc1nccnc1-c1ccccc1</smiles>

8<smiles>COc1ccc(-c2ncc(O)nc2-c2ccc(OC)cc2)cc1</smiles>

9<smiles>Cc1nc(-c2ccccc2)c(-c2ccccc2)nc1Cl</smiles>

10<smiles>Brc1cnc(-c2ccccc2)nc1-c1ccccc1</smiles>

11<smiles>Cc1ccc(-c2nc(O)c(O)nc2-c2ccc(C)cc2)cc1</smiles>

12<smiles>Brc1ccc(-c2nccnc2-c2ccc(Br)cc2)cc1</smiles><smiles>CCCC</smiles> 
main of the developed model. The structures and activities of these compounds are reported in table 12 .

\section{Conclusion}

The present work deals with the molecular properties of pyrazine. The HF, MP2 and DFT methods, the DFT method is more appropriate for further study on pyrazine rings. The geometry of the pyrazine is symmetric and planar, as all the dihedral angles are either nearly $0^{\circ}$ or $180^{\circ}$, which makes this conformation more stable. The compound $\mathrm{B} 3$ (2,3-dibromo pyrazine) is predicted to be the most reactive with a smaller HOMO-LUMO energy gap of all pyrazine systems, $\mathrm{C} 2$ and $\mathrm{C} 3$ positions are the most preferential site of nucleophilic attack.

Afterward, we showed that both ANN and MLR methods provide similar QSAR model accuracy. As can be seen in Table 11, the ANN network has substantially better predictive capabilities compared to MLR, leading to pIC50 values closer to the experimental determinations. Nevertheless, both models remain satisfactory and exhibit a high predictive power, thus validating their use to explore and propose new molecules as anti-proliferative activity against the BGC823.

Based on the obtained QSAR equation we have identified a series of potential novel compounds of pyrazine. This series has been used as a primary step for predicting the anti-proliferative activity against the BGC823. It is worth testing the reliability of these predictions in vitro, our work should help in identifying new compounds targeting anti-proliferative activity against the BGC823.

\section{References}

1. V. M. Baldwin, S. D. Arikkatt, T. J. Sindhu, M. Chanran, A. R. Bhat, K. Krishnakumar, World J. Pharm. Sci. 2014, 3, 11241132.

2. D. L. Trump, H. Payne, K. Miller, J. S. de Bono, J. Stephenson, H. Burris, F. Nathan, M. Taboada, T. Morris, A. Hubner, J. of Prostate, 2011, 71, 1264-1275. DOI:10.1002/pros.21342

3. C. P. Meher, A. M. Rao, Md. Omar, Asian J. Pharm. Sci. \& Res. 2013, 3, 52-56.

4. L. E. Schechter, Q. Lin, D. L. Smith, G. Zhang, Q. Shan, B. Platt, M. R. Brandt, L. A. Dawson, D. Cole, R. Bernotas, A. Robichaud, S. Rosenzweig-Lipson, C.E. Beyer, Int. J. Neuropsychopharmacol. 2008, 33, 1323-1335.

DOI:10.1038/sj.npp.1301503

5. S. Spaia, I. Magoula, G. Tsapas, G. Vayonas, Perit. Dial. Int. 2002,20, 47-52. DOI:10.1177/089686080002000109

6. K. Whalen, "Pharmacology", $6^{\text {th }}$ edition, University of Florida, College of Pharmacy Gainesville, Gainesville, Florida, USA, 2014.

7. S. Rosenzweig-Lipson, J. Zhang, H. Mazandarani, L. H. Boyd, A. sabb,J. Sabalski,G. Stack,G. Welmaker,J. E. Barrett, J. Dun- lop, Brain Res. 2006, 1073-1074, 240-251.

DOI:10.1016/j.brainres.2005.12.052

8. W. J. Hehre: Practical Strategies for Electronic Structure Calculations, Wave functions, Irvine, California,USA, 1995.

9. I. H. Nazlı, D. B. Celepci, G. Yakali, D. Topkaya, M. Aygün, S. Alp, Acta Chim. Slov. 2018, 65, 86-96.

DOI:10.17344/acsi.2017.3613

10. F. Odame, Acta Chim. Slov. 2018, 65, 328-332. DOI:10.17344/acsi.2017.4001

11. S. Belaidi, R. Mazri, H. Belaidi, T. Lanez, D. Bouzidi, Asian J. Chem. 2015, 25, 9241-9245. DOI:10.14233/ajchem.2013.15199

12. Z. Haddadi, H. Meghezzi, A. Amar,A. Boucekkine, J. Theor. Comput. Chem. 2019, 31, 595-601. DOI:10.1142/S0219633619500019

13. A. K. Sachan, S. K. Pathak, S. Chand, R. Srivastava, O. Prasad, S. Belaidi, L. Sinha, Spectrochim. Acta A Mol. Biomol. Spectrosc. 2014, 132,568-581. DOI:10.1016/j.saa.2014.05.011

14. S. Belaidi, Z. Almi, D. Bouzidi, J. Comput. Theor. Nanosci. 2014,11, 2481-2488. DOI:10.1166/jctn.2014.3665

15. C. M. Chang, H. L. Tseng, A. F. Jalbout, A. de Leon, J. Comput. Theor. Nanosci.2013, 10, 527-533.

DOI: $10.1166 /$ jctn.2013.2730

16. T. L. Jensen, J. Moxnes, E. Unneberg, J. Comput. Theor. Nanosci. 2013, 10, 464-469. DOI:10.1166/jctn.2013.2720

17. M. Ibrahim, H. Elhaes, Rev. Theor.Sci. 2013, 1, 368-376. DOI:10.1166/rits.2013.1012

18. E. C. Anota, H. H. Cocoletzi, M. Castro, J. Comput. Theor. Nanosci. 2013, 10,2542-2546. DOI:10.1166/jctn.2013.3244

19. F. Bazooyar, M. Taherzadeh, C. Niklasson, K. Bolton, J. Comput. Theor. Nanosci. 2013, 10, 2639-2646. DOI: $10.1166 /$ jctn.2013.3263

20. E. R. Davidson : Quantum Theory of Matter,Chem.Rev., guest editor, department of chemistry, Indiana university,India, 1991,91, 649. DOI:10.1021/cr00005a600

21. S. Belaidi, H. Belaidi, D. Bouzidi, J. Comput. Theor. Nanosci. 2015, 12,1737-1745. DOI:10.1166/jctn.2015.3952

22. B. Souyei, A. Hadj Seyd, F. Zaiz,A. Rebiai, Acta Chim. Slov. 2019, 66, 315-325. DOI:10.17344/acsi.2018.4793

23. R. A. Gupta,A. K. Gupta, S. G. Kaskhedikar, Acta Chim. Slov. 2009, 56, 977-984.

24. E. Zerroug,S. Belaidi,I. Benbrahim,S. Leena, J. King Saud Univ. Sci. 2019, 31, 595-601.

DOI:10.1016/j.jksus.2018.03.024

25. F. Soualmia, S. Belaidi, N. Tchouar, T. Lanez, J. Fundam. Appl. Sci. 2020, 12, 392-415. DOI: 10.4314/jfas.v12i1S.28.

26. Y. C. Martin: Quantitative Drug Design, Marcel Dekker, New York, USA, 1978.

27. I. Almi, S. Belaidi, E. Zerroug, M. Alloui, R. G. Ben Said, R. Linguerri, M. Hochlaf, J. Mol. Struct. 2020, 1211,128015. DOI:10.1016/j.molstruc.2020.128015

28. C. A. Lipinski, V. Lombardo, B. W. Dominy, P. J. Feeney, $A d v$. Drug Deliv. Rev. 2001, 46, 3-26.

DOI:10.1016/S0169-409X(00)00129-0

29. E. L. Pankratov, E. A. Bulaeva, Rev. Theor. Sci. 2013, 1, 58-82. DOI:10.1166/rits.2013.1004 
30. Q. Zhao, Rev. Theor. Sci. 2013, 1, 83-101.

DOI:10.1166/rits.2013.1005

31. A. Khrennikov, Rev. Theor. Sci. 2013, 1, 34-57.

DOI:10.1166/rits.2013.1003

32. V. Paitya, K. P. Ghatak, Rev. Theor. Sci. 2013, 1,165-305. DOI:10.1166/rits.2013.1008

33. D. Fiscaletti, Rev. Theor. Sci. 2013,1, 103-144. DOI:10.1166/rits.2013.1006

34. D. M. Segall, J. Curr. Pharm. Des. 2012, 18,1292-1310. DOI:10.2174/138161212799436430

35. R. Darnag, B. Minaoui, M. Fakir, Arab. J. Chem. 2017, 10,600608. DOI:10.1016/j.arabjc.2012.10.021

36. P. Xuan, Y. Zhang, T. J. Tzeng, X. F. Wan, F. Luo, Glycobiology, 2012, 22, 554-560. DOI:10.1093/glycob/cwr163

37. S. Kothiwale, C. Borza, A. Pozzi, J. Meiler, Molecules. 2017, 22, 1576-1586. DOI:10.3390/molecules22091576

38. Z. Hajimahdi, A. Ranjbar, A. A. Suratgar, A. Zarghi, Iran. J. Pharm. Res. 2014, 14, 69-74.

39. M. Ghamri, D. Harkati, S. Belaidi, S. Boudergua, R. Ben Said, R. Linguerri, G. Chambaud, M. Hochlaf, Spectrochim. Acta A Mol. Biomol. Spectrosc. 2020, 242, 118724.

DOI:10.1016/j.saa.2020.118724

40. S. Boudergua, M. Alloui, S. Belaidi, M. Mogren Al Mogren,U. A. Abd Ellatif Ibrahim, M. Hochlaf, J. Mol. Struct. 2019, 1189, 307-314. DOI:10.1016/j.molstruc.2019.04.004

41. E. Pourbasheer, S. Vahdani, D. Malekzadeh, R. Aalizadeh, A. Ebadi, Iran. J. Pharm. Res.2017, 16, 966-980.

42. HyperChem (Molecular Modeling System) Hypercube, Inc., 1115 NW, 4th Street, Gainesville, FL 32601, USA (2008).

43. Gaussian 09, M. J. Frisch, G. W. Trucks, H. B. Schlegel, G. E. Scuseria, M. A. Robb, J. R. Cheeseman, G. Scalmani, V. Barone, B. Mennucci, G. A. Petersson, H. Nakatsuji, M. Caricato, X. Li, H. P. Hratchian, A. F. Izmaylov, J. Bloino, G. Zheng, J. L. Sonnenberg, M. Hada, M. Ehara, K. Toyota, R. Fukuda, J. Hasegawa, M. Ishida, T. Nakajima, Y. Honda, Y. Kitao, H. Nakai, T. Vreven, J. A. Montgomery, J. E. Peralta, F. Ogliaro, M. Bearpark, J. J. Heyd, E. Brothers, K. N. Kudin, V. N. Staroverov, T. Keith, R. Kobayashi, J. Normand, K. Raghavachari, A. Rendell, J. C. Burant, S. S. Iyengar, J. Tomasi, M. Cossi, N. Rega, J. M. Millam, M. Klene, J. E. Knox, J. B. Cross, V. Bakken, C. Adamo, J. Jaramillo, R. Gomperts, R. E. Stratmann, O. Yazyev, A. J. Austin, G. A. Cammi R., Pomelli C., Ochterski J. W., Martin R. L., Morokuma K., Zakrzewski V. G., Voth, P. Salvador, J. J. Dannenberg, S. Dapprich, A. D. Daniels, O. Farkas, J. B. Foresman, J. V. Ortiz, J. Cioslowski, D. J. Fox, Gaussian Inc., Wallingford, CT(2010).

44. MarvinSketch15.8.31, Chemaxon (http://www.chemaxon. com) (2015).

45. Database,(http://www.molinspiration.com).

46. JMP 8.0.2, SAS Institute Inc., (2009).

47. M. Kanno, Y. Ito, N. Shimakura, S. Koseki, H. Kono, Y. Fujimura, J. Phys. Chem.- Chem.Phys. 2015, 17, 2012-2024.

DOI:10.1039/C4CP04807E

48. P. Govindasamy, S. Gunasekaran, J. Mol. Struct. 2015, 1081, 96-109. DOI:10.1016/j.molstruc.2014.10.011

49. J. S. Murray, K. Sen, Molecular Electrostatic Potentials, $1^{\text {st }}$
Edition, Concepts and Applications, Elsevier, Amsterdam, Holland, 1996.

50. I. Alkorta, J. J. Perez, Int. J. Quantum Chem. 1996, 57, 123-135. DOI:10.1002/(SICI)1097-461X(1996)57:1<123::AID-QUA $14>3.0 . \mathrm{CO} ; 2-9$

51. E. Scrocco, J. Tomasi, Adv. Quantum Chem. 1978, 11, 115193. DOI:10.1016/S0065-3276(08)60236-1

52. F. J. Luque, M. Orozco, P. K. Bhadane, S. R. J. Gadre, J. Phys. Chem. 1993, 97, 9380-9384. DOI:10.1021/j100139a021

53. J. Sponer, P. Hobza, J. Quantum Chem.1996, 57, 959-970. DOI:10.1002/(SICI) 1097-461X(1996)57:5<959::AID-QUA $16>3.0 . \mathrm{CO} ; 2-\mathrm{S}$

54. J. M. Seminario, Recent Developments and Applications of Modern Density Functional Theory, Elsevier, Amsterdam, Holland, 1996. DOI:10.1016/S1380-7323(96)80082-3

55. I. Fleming: Frontier orbitals and organic chemical reactions, Wiley, New York, USA, 1976.

56. G. L. Miessler, D. A. Tarr: Inorganic Chemistry, $2^{\text {nd }}$ edition, Prentice-Hall Upper Saddle River, New Jersey, USA, 1999.

57. Y. B. Zhang, X. L. Wang, W. Liu, Y. S. Yang, J. F. Tang, H. L. Zhu, Bioorg. Med. Chem. 2012, 20, 6356-6365. DOI:10.1016/j. bmc.2012.08.059

58. C. A. Lipinski, F. Lombardo, B. W. Dominy, P. J. Feeney, J. Adv. Drug Deliv. Rev. 2 012, 64, 4-17.

DOI:10.1016/j.addr.2012.09.019

59. D. F. Veber, S. R. Johnson, H. Y. Cheng, B. R. Smith, K. W. Ward, K. D. Kopple, J. Med. Chem.2002, 45, 2615-2623. DOI:10.1021/jm020017n

60. M. Aurélien, Ph.D. Dissertation, Orleans University, France, 2006.

61. F. Soualmia, S. Belaidi, H. Belaidi, N. Tchouar, Z. Almi, J. Bionanosci. 2017, 11, 584-591.

DOI:10.1166/jbns.2017.1476

62. B. Jhanwarb, V. Sharmaa, R. K. Singla, B. Shrivastava, Pharmacologyonline. 2011, 1, 306-344.

63. R. Darnag, B. Minaoui, M. Fakir, Arab. J. Chem. 2017, 10,600608. DOI:10.1016/j.arabjc.2012.10.021

64. I. Hammoudan, S. Matchi, M. Bakhouch, S. Belaidi,Chemistry, 2021, 3(1):391-401. DOI:10.3390/chemistry3010029

65. R. Dahmani, M. Manachou, S. Belaidi, S. Chtita, S. Boughdiri, New J. Chem. 2021, 45(3), 1253-1262.

DOI:10.1039/D0NJ05298A

66. K. Roy, S. Kar, R. N. Das, A Primer on QSAR/QSPR Modeling: Fundamental Concepts, Springer, New York, USA, 2015.

67. S. Erić, M. Kalinić, A. Popović, M. Zloh, I. Kuzmanovski, Int. J. Pharm. 2012, 437, 232-241.

DOI:10.1016/j.ijpharm.2012.08.022

68. R. Lowe, H. Y. Mussa, J. B. Mitchell, R. C. Glen, J. Chem. Inf. Model. 2011, 51,1539-1544. DOI:10.1021/ci200128w

69. E. Zerroug,S. Belaidi, S. Chtita, J. Chin. Chem. Soc. 2021, 68(2), 197-384. DOI:10.1002/jccs.202000457

70. F. Z. Fadel, N. Tchouar, S. Belaidi, F. Soualmia, O. Oukil, and K. Ouadah, J. Fundam. Appl. Sci., 2021, 13(2), 942-964. DOI:10.43 14/jfas.v13i2.17.

71. C. Feng, S. Vijaykumar, Clin. Exp. Pharmacol. 2012, 2, $2-3$. DOI:10.4172/2161-1459.1000e113 
72. B. D. Ripley, Pattern Recognition and Neural Networks, Cambridge University Press, NY United States, USA, 1996.
73. P. Ghosh, A. Mandal, Green Chem. Lett. Rev., 2012, 5(2), 127-134. DOI:10.1080/17518253.2011.585182

\section{Povzetek}

Preučevali smo elektronske strukture, vpliv substitucije, povezavo med strukturno fizikalno-kemijskimi lastnostmi ter aktivnostjo in učinkovinske podobnosti (ang. drug-likeness) pirazinskih derivatov s pomočjo ab initio (HF, MP2) in B3LYP/DFT (teorijo gostotnega fukcionala). V članku smo izračunali vrednosti naboja NBO (naravnih veznih orbital), dolžino vezi, dipolne momente, elektronsko afiniteto, tvorbeno entalpijo in QSAR lastnosti. Študij QSAR smo izvedli $s$ pomočjo statističnih modelov multiple linearne regresije in nevronskih mrež (ANN). Rezultati so pokazali visoko korelacijo med eksperimentalnimi in napovedanimi vrednostmi, s čimer smo preverili in pokazali ustreznost QSAR modelov. Statistična analiza je pokazala, da je ANN z arhitekturo 9-4-1 bolj ustrezna kot MLR. Pregled različnih molekul na osnovi molekularne podobnosti in uporabe QSAR domen je pokazal več kandidatov z izboljšanim antiproliferativnim delovanjem. 